\author{
A. Simeonova, S. Petkova \\ Technical University - Varna, Bulgaria

\section{BIOSORPTION OF HEAVY METALS BY MARINE ALGAE ULVA RIGIDA, CYSTOSEIRA BARBATA AND C. CRINITA}

\begin{abstract}
Adsorption properties of three different marine algae (Ulva rigida (green algae); Cystoseira barbata (brown algae) and Cystoseira crinita (brown algae)) were investigated. They were collected from the Black Sea coastal area in Varna region, Bulgaria. Kinetics were studied to evaluate the ability of the three algae to sequester $\mathrm{Cu}$ (II), $\mathrm{Zn}$ (II), $\mathrm{Pb}$ (II), $\mathrm{Ni}$ (II), $\mathrm{Cd}$ (II) from aqueous solution. The maximum biosorption capacity obtained was $2.84 \mathrm{mgeq} \mathrm{Ni}^{2+} / \mathrm{g}$ for Cystoseira crinita and $2.28 \mathrm{mgeq} \mathrm{Cu}^{2+} / \mathrm{g}$ for Cystoseira barbata at a solution $p H$ of $5 \pm 0.5$. The influence of $p H$ of the solution and algae mass on the heavy metal sorption was investigated either. Desorption using $0.05 \mathrm{M} \mathrm{HNO}_{3}$ was carried out and was determined that regeneration of biomass for use in multiple cycles of $C d$ (II) biosorption -desorption should be feasible.

Вивчали адсорбційні властивості трьох морських водоростей (Ulva rigida (зелені), Cystoseira barbata (бурі) та Cystoseira crinita (бурі)), вплив $p H$ і маси водорості на сорбцію важких металів. Оцінювали здатність водоростей зв'язувати мідь (II), цинк (II), свинець (II), нікель (II) і кадмій (II). Максимальна визначена біосорбція становила 2,84 мг-екв. $\mathrm{Ni}^{2+} / \Gamma$ для Cystoseira crinita i 2,28 мг-екв. $\mathrm{Cu}^{2+} / г$ для $C$. barbata при $\mathrm{pH}=5 \pm 0,5$. Десорбція з використанням 0,05 М $\mathrm{HNO}_{3}$ показала, що регенерація біомаси та багаторазові цикли “біосорбції - десорбції” кадмію цілком можливі.
\end{abstract}

\title{
Introduction
}

Heavy metal contamination exists in aqueous waste streams of many industries, such as metal plating facilities, mining operations, and tanneries. Heavy metals are not

Вісник Дніпропетровського університету. Біологія, екологія. Vìsnik Dnìpropetrovs'kogo unìversitetu. Serìâ Bìologîâ, ekologiâ Visnyk of Dnipropetrovsk University. Biology, ecology. Vìsn. Dnìpropetr. Unìv. Ser. Bìol. Ekol. 2007. 15(1). 
biodegradable and tend to accumulate in living organisms. To curtail heavy metal pollution problems, many processes have been developed for the treatment of metal containing waste waters.

The need for economical, effective and safe methods for removing heavy metals from waste waters has resulted in the search for unconventional materials that may be useful in reducing the levels of heavy metals in the environment. In this light, biological materials have emerged as an ecofriendly and economic option. Biosorption, which uses the ability of biological materials to remove and accumulate heavy metals from aqueous solutions, has received considerable attention in recent years because of few advantages compared to traditional methods. Biosorption uses cheaper materials such as naturally abundant algae or byproducts of fermentation industries as biosorbents $[4 ; 11 ; 15-17]$.

Among the biological materials investigated for heavy metal removal, the biomass of marine algae otherwise known as seaweeds has been reported to have high uptake capacities for a number of heavy metal ions [1; 18]. Numerous studies of metal biosorption by brown algae such as Sargassum have been reported in literature $[5 ; 8 ; 9 ; 12]$. The role of the cellular structure, storage polysaccharides, cell wall has been evaluated in terms of their potential for metal sequestration.

The brown seaweeds Sargassum hemiphyllum, Petalinia fascia and Colpomenia sinusa has been characterized by their number of binding sites [13]. Due to their high number of binding sites Sargassum and Petalinia has been determined to be the most promising for biosorption application.

Many investigations have been carried out for biosorption of heavy metals by the other important divisions of algae Green algae (Chlorophyta) and Red algae (Rhodophyta) $[7 ; 14]$. Ulva reticulate was the focus of the study of Kuppusamy Vijayaraghavan et al. The influence of several factors such as $p H$, initial metal concentration and contact time were analyzed [3]. Green algae Cladophora fascicularis was determined by Liping Dend et al to be an effective and economical biosorbent material for the removal of heavy metal ions [2].

In the present study, the biosorption of heavy metal ions such as $\mathrm{Cu}$ (II), $\mathrm{Zn}$ (II), $\mathrm{Pb}$ (II), $\mathrm{Ni}$ (II), $\mathrm{Cd}$ (II) by three different marine algae Ulva rigida (green algae), Cystoseira barbata (brown algae) and Cystoseira crinita (brown algae) was investigated. The effect of contact time, concentration of algal biomass, $p H$ and regeneration were studied.

\section{Materials and methods}

Green algae Ulva rigida and brown algae Cystoseira barbata and Cystoseira crinita are used for investigation of heavy metal ion sorption. They were collected from the Black Sea coastal area in Varna region, Bulgaria. Heavy metal solutions ware prepared by solving of $\mathrm{Pb}\left(\mathrm{NO}_{3}\right)_{2}, \mathrm{Cu}\left(\mathrm{NO}_{3}\right)_{2} .3 \mathrm{H}_{2} \mathrm{O}, \mathrm{Ni}\left(\mathrm{NO}_{3}\right)_{2} .6 \mathrm{H}_{2} \mathrm{O}, \mathrm{Zn}\left(\mathrm{NO}_{3}\right)_{2}$ and $\mathrm{Cd}\left(\mathrm{NO}_{3}\right)_{2}$ in deionized water. All reagents were analytical grade. Ulva rigida, Cystoseira barbata and Cystoseira crinita were harvested from Black Sea and were washed several times using deionized water to remove the sand particles and salts. They were then dried at room temperature to constant weight. Dry biomass was chopped to $1,5 \mathrm{~cm}$ particles which were used for biosorption experiments.

All batch biosorption experiments were carried out by adding $1 \mathrm{~g}$ of dried biomass to $50 \mathrm{~cm}^{3}$ of heavy metal ion solutions in Erlenmeyer flasks. The flasks were agitated at $250 \mathrm{rpm}$ for $60 \mathrm{~min}$. The experiments were conducted at room temperature $\left(20^{\circ} \mathrm{C}\right)$ at pH $5 \pm 0.5$. Samples were taken at regular intervals till equilibrium was reached. The residual metal concentration in the solution was determined by EDTA titration. The metal uptake was calculated by the following equation:

Вісник Дніпропетровського університету. Біологія, екологія.

Vìsnik Dnìpropetrovs'kogo unìversitetu. Seriâ Bìologîa, ekologîâ Visnyk of Dnipropetrovsk University. Biology, ecology. Vìsn. Dnìpropetr. Unìv. Ser. Bìol. Ekol. 2007. 15(1).

ISSN 2310-0842 print ISSN 2312-301X online www.ecology.dp.ua 


$$
a=\frac{\left(C_{0}-C_{f}\right) V}{1000 . m},[\mathrm{mg} / \mathrm{g}]
$$

where $V$-volume of the solution in the contact batch flask $\left(\mathrm{cm}^{3}\right), C_{0}$ - initial concentration of the metal ions $\left(\mathrm{mg} / \mathrm{dm}^{3}\right), C_{f}$ - equilibrium concentration $\left(\mathrm{mg} / \mathrm{dm}^{3}\right), m$ - weight of the sorbent $(\mathrm{g})$.

Algal mass quantity was varied from 0,1 to $1 \mathrm{~g}$ to study its influence upon sorption. For studying the influence of $p H$ on the biosorption, experiments were conducted at various initial metal solution $p H$ values of 2-8. To avoid hydroxide precipitation at high $p H$, ammonium acetate was added [8]. All experiments were carried out in triplicate to check the reproducibility of results. The desorption of heavy metal ions was carried out using $0,05 \mathrm{M}$ $\mathrm{HNO}_{3}$. The biosorbents were eluted for $60 \mathrm{~min}$. After acid elution, deionized water was used to rinse the biomass until the $p H$ of the wash effluent exceeded 6.0. The regenerated biosorbents then were used for next sorption. The effect of regeneration was determined by the following equation:

$$
E p=\frac{a_{1}}{a_{n}} \cdot 100,[\%]
$$

where $a_{1}$ - metal uptake of the fresh biosorbent, $a_{n}$ - metal uptake of the regenerated biosorbent.

\section{Results and discussion}

In the present study the sorption characteristics of three biosorbents were examined Ulva rigida (green algae), Cystoseira barbata and C. crinita (brown algae) with regard to $\mathrm{Pb}$ (II), $\mathrm{Cu}$ (II), $\mathrm{Ni}$ (II), $\mathrm{Cd}$ (II) and $\mathrm{Zn}$ (II) ions. The biosorbents were harvested from the Black Sea coastal area in Varna region, Bulgaria during October. For kinetic experiments, $1 \mathrm{~g}$ biomass was added in $50 \mathrm{~cm}^{3}$ metal solution at initial $\mathrm{pH} 5 \pm 0.5$ and initial concentration of the solution $1 \mathrm{~g} / \mathrm{dm}^{3}$. Fig. 1, 2 and 3 shows the kinetics of heavy metal ions uptake onto Ulva rigida, Cystoseira barbata and C. crinita. The plots represent the heavy metal uptake a (mgeq/g) versus time. It was observed that equilibrium was reached for a period of 15-30 min. Significant proportion of metal ions was removed from solution within the first 10 min of agitation and no further significant adsorption was observed beyond that period.

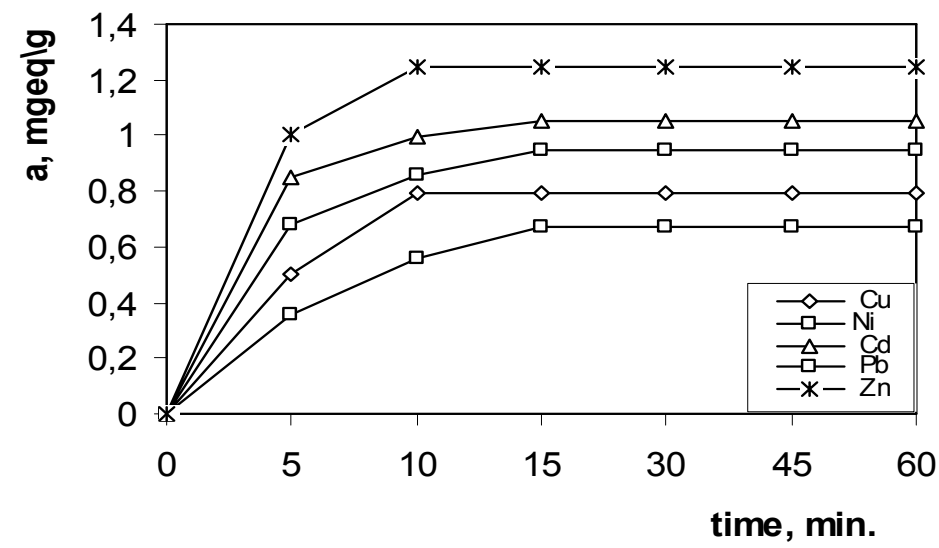

Fig. 1. Kinetics of heavy metal ions uptake onto Ulva rigida

Each of the biosorbents showed different affinity toward heavy metals. This could be explained with the difference in cell wall composition and the intra group differences which cause significant differences in the type and amount of metal ion binding to them. The cell wall consists of variety of polysaccharides and proteins which offers a number of active sites capable of bindind metal ions. The highest uptake of the investigated biosorbents is

Вісник Дніпропетровського університету. Біологія, екологія.

Vìsnik Dnìpropetrovs'kogo unìversitetu. Serîa Bìologîa, ekologîâ Visnyk of Dnipropetrovsk University. Biology, ecology. Vìsn. Dnìpropetr. Unìv. Ser. Bìol. Ekol. 2007. 15(1).

ISSN 2310-0842 print ISSN 2312-301X online www.ecology.dp.ua 
shown in table 1. Ulva rigida exhibited highest uptake with regard to $Z n$ (II) $-1.25 \mathrm{mgeq} / \mathrm{g}$; Cystoseira barbata to $\mathrm{Cu}$ (II) $-2.28 \mathrm{mgeq} / \mathrm{g}$ and C. crinita to $\mathrm{Ni}$ (II) $-2.84 \mathrm{mg} / \mathrm{g}$. According to the results for biomass batch sorption the following metal order was obtained for each biosorbent:

$$
\begin{aligned}
& \text { Ulva rigida }-\mathrm{Zn}>\mathrm{Cd}>\mathrm{Ni}>\mathrm{Cu}>\mathrm{Pb}, \\
& \text { Cystoseira barbata }-\mathrm{Cu}>\mathrm{Zn}>\mathrm{Cd}>\mathrm{Ni} \sim \mathrm{Pb}, \\
& \text { C. crinita }-\mathrm{Ni}>\mathrm{Cu}>\mathrm{Zn}>\mathrm{Cd}>\mathrm{Pb} .
\end{aligned}
$$

Heavy metals maximum uptake (mgeq/g) by Ulva rigida, Cystoseira barbata, $C$. crinita; initial concentration of metal ions $-1 \mathrm{~g} / \mathrm{dm}^{3}, \mathrm{pH} 5$

\begin{tabular}{|l|c|c|c|c|c|}
\hline \multicolumn{1}{|c|}{ Sorbents } & $C u(\mathrm{II})$ & $C d(\mathrm{II})$ & $\mathrm{Ni}(\mathrm{II})$ & $\mathrm{Pb}(\mathrm{II})$ & $\mathrm{Zn}$ (II) \\
\hline Ulva rigida & 0.79 & 1.05 & 0.95 & 0.67 & 1.25 \\
\hline Cystoseira barbata & 2.28 & 1.20 & 0.80 & 0.80 & 1.25 \\
\hline Cystoseira crinita & 1.56 & 1.25 & 2.84 & 0.69 & 1.50 \\
\hline
\end{tabular}

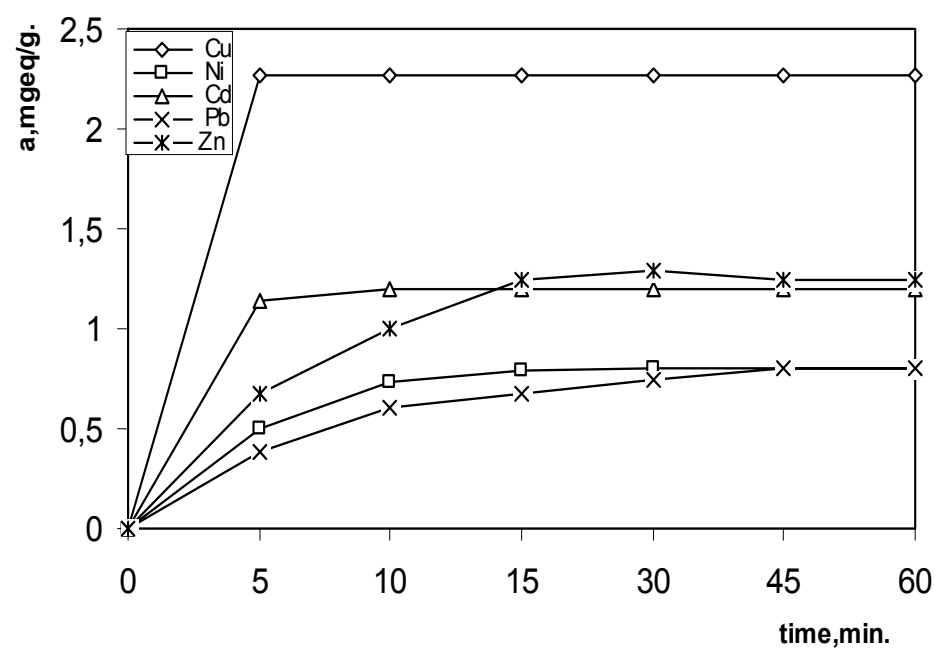

Fig. 2. Kinetics of heavy metal ions uptake onto Cystoseira barbata

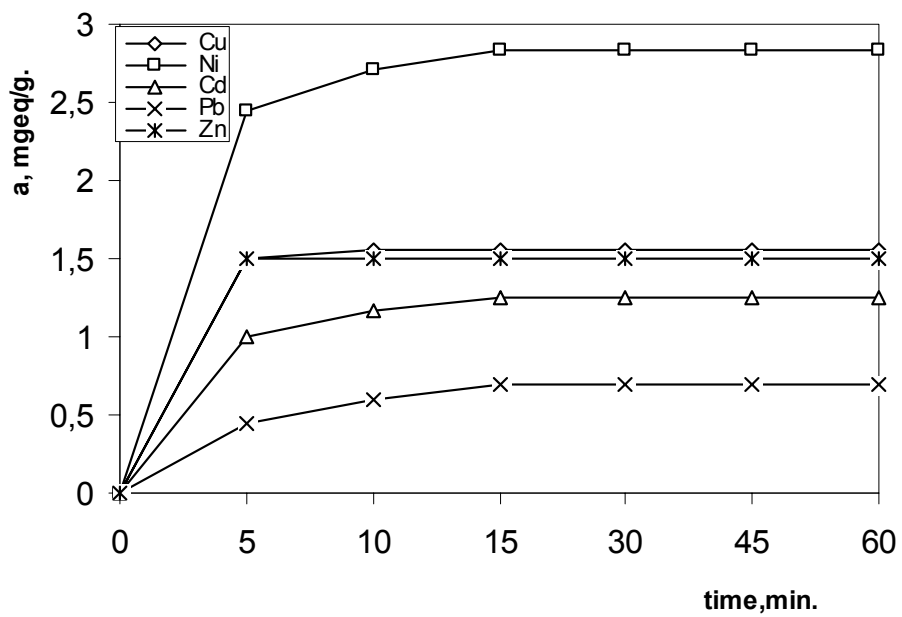

Fig. 3. Kinetics of heavy metal ions uptake onto Cystoseira crinita

Вісник Дніпропетровського університету. Біологія, екологія.

Vìsnik Dnìpropetrovs'kogo unìversitetu. Serìa Bìologîa, ekologîâ Visnyk of Dnipropetrovsk University. Biology, ecology. Vìsn. Dnìpropetr. Unìv. Ser. Bìol. Ekol. 2007. 15(1)

ISSN 2310-0842 print ISSN 2312-301X online www.ecology.dp.ua 
The brown algae Cystoseira barbata and C. crinita exhibited highest uptake with regard to most of the heavy metal ions. In brown algae biomass, alginate in the cell wall is the main component responsible for the metal sorption. It is present in a gel form which appears very porous and easily permeable [6]. This could explain the highest uptake of metal ions.

The exploitation of biosorbents for removal of heavy metals depends on the efficiency of the regeneration after metal sorption. The desorption of metals in this study was investigated using dilute mineral acid $0.05 \mathrm{M} \mathrm{HNO}_{3}$ as desorbing agent. The effect of regeneration (Ep) was calculated and presented in fig. 4, 5 and 6. The three sorbents exhibited effect of regeneration regarding $\mathrm{Pb}$ (II), $\mathrm{Cu}$ (II), $\mathrm{Zn}$ (II) and $\mathrm{Ni}$ (II) fewer than $50 \%$ after the II cycle. Good regeneration and high sorption capacity after multiple cycles showed the three biosorbents with regard to $C d$ (II).The most effective regeneration with regard to $C d$ (II) was reached by Ulva rigida ( $82 \%$ after the IV cycle). During regeneration Cystoseira barbata and C. crinita showed higher mechanical stability than Ulva rigida where the elution resulted in some changes in the cell structure of the green algae. Thus, regeneration of the biosorbents for use in multiple cycles of $C d$ (II) biosorption - desorption should be feasible.

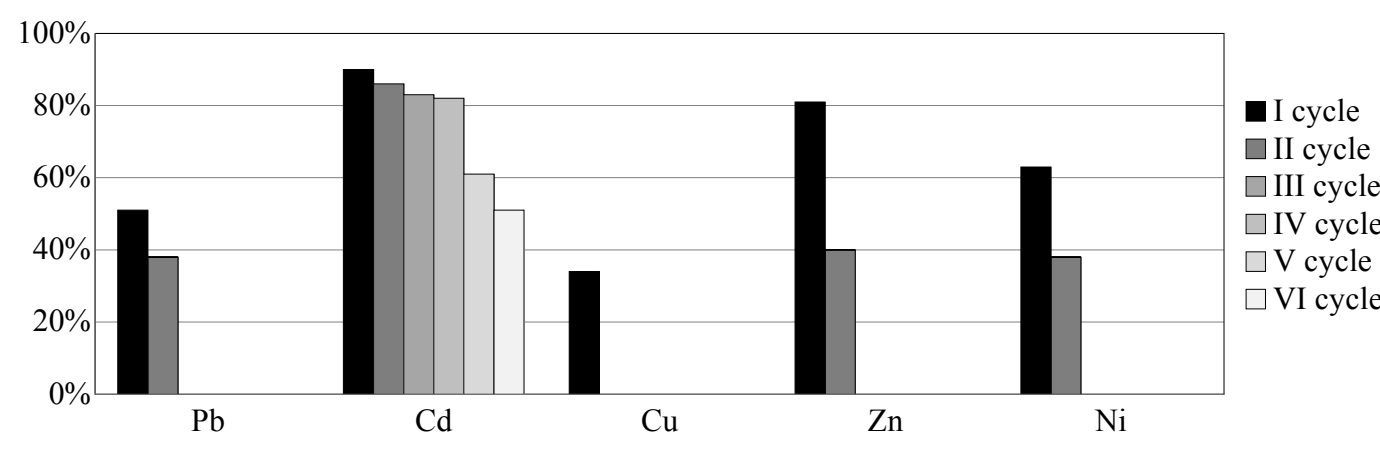

Fig. 4. Effect of regeneration of Ulva rigida

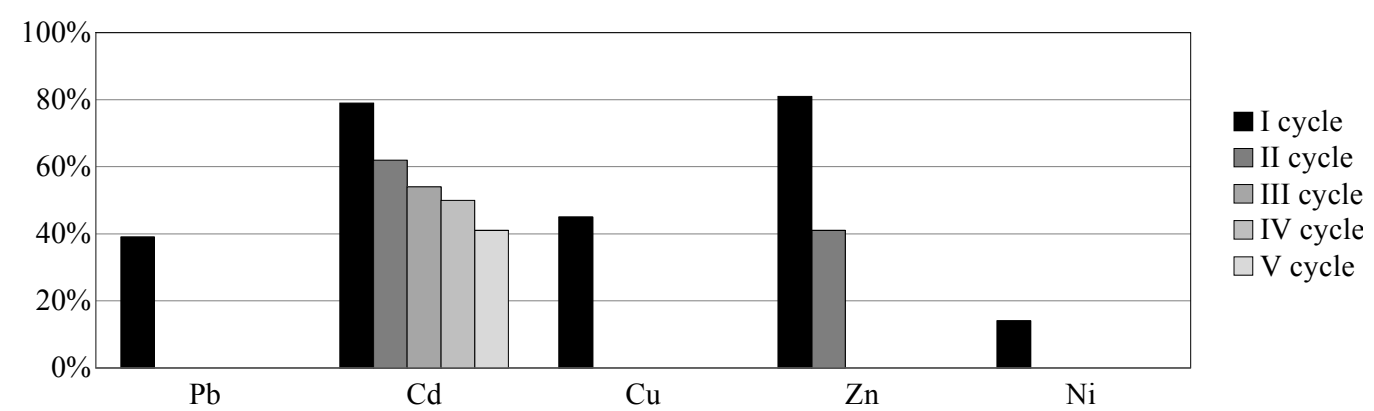

Fig. 5. Effect of regeneration of Cystoseira barbata

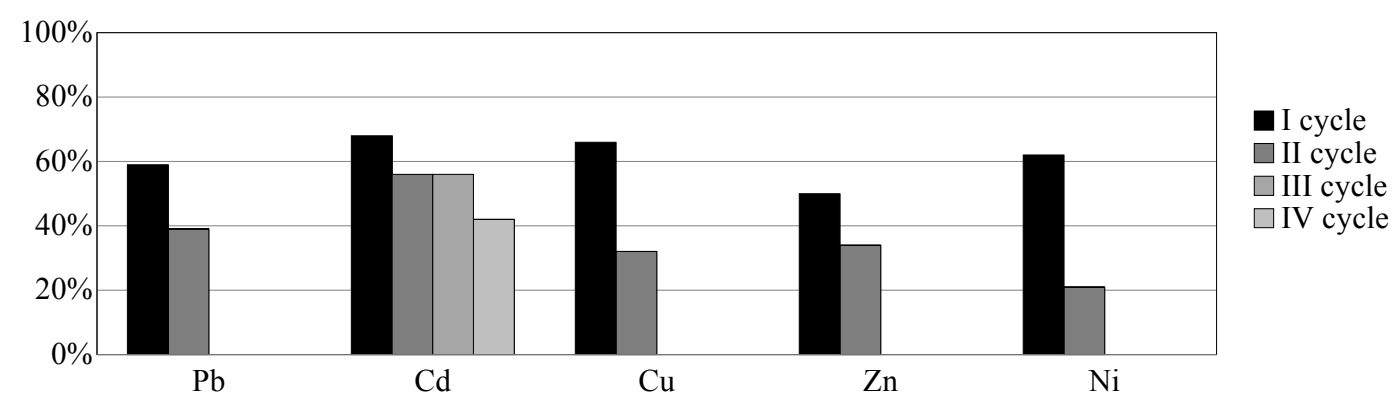

Fig. 6. Effect of regeneration of Cystoseira crinita

Вісник Дніпропетровського університету. Біологія, екологія. Vìsnik Dnìpropetrovs'kogo unìversitetu. Serîa Bìologîa, ekologîâ Visnyk of Dnipropetrovsk University. Biology, ecology. Vìsn. Dnìpropetr. Unìv. Ser. Bìol. Ekol. 2007. 15(1).

ISSN 2310-0842 print ISSN 2312-301X online www.ecology.dp.ua 
The effect of Cystoseira barbata and $C$. crinita mass for the removal of $C u$ (II) and $\mathrm{Ni}$ (II) was studied using algal mass in the range of 100-1000 mg. Batch sorption is carried out till equilibrium was reached and sorption effect was calculated by the following equation:

$$
E=\left(C_{0}-C_{f}\right) / C_{0} \cdot 100 \text {, }
$$

where $C_{0}$ - initial concentration of the metal ions $\left(\mathrm{mg} / \mathrm{dm}^{3}\right), C_{f}$ - equilibrium concentration $\left(\mathrm{mg} / \mathrm{dm}^{3}\right)$. Results showed an increased uptake of $\mathrm{Cu}$ (II) and $\mathrm{Ni}$ (II) with the increase of algae quantity (tab. 2, 3). C. barbata exhibited $90 \%$ effect of $C u$ (II) sorption at about $1000 \mathrm{mg}$ mass.

Table 2

\section{Effect of sorption of $C u$ (II) by Cystoseira barbata at different algae mass}

\begin{tabular}{|c|c|c|c|}
\hline Mass of the sorbent, $\mathrm{mg}$ & $C_{o}$ & $C_{f}$ & $E, \%$ \\
\hline 100 & 1.9 & 1.59 & 16 \\
\hline 200 & 1.9 & 1.27 & 33 \\
\hline 500 & 1.9 & 1.27 & 33 \\
\hline 800 & 1.9 & 0.95 & 50 \\
\hline 1000 & 1.9 & 0.19 & 90 \\
\hline
\end{tabular}

Marine algae contain high content of ionizable groups on the cell polysaccharides, which suggests that the biosorption process could be affected by changes in the solution $p H$ $[4 ; 10]$. In the present study was investigated the influence of $p H$ on the sorption uptake of Cystoseira crinita with regard to $\mathrm{Ni}$ (II) and $\mathrm{C}$. barbata to $\mathrm{Cu}$ (II).The experiments were carried out at $p H$ interval $2-8$ and the results are presented in fig. 7.

Table 3

Effect of sorption of $\mathrm{Ni}$ (II) by Cystoseira crinita at different algae mass

\begin{tabular}{|c|c|c|c|}
\hline Mass of the sorbent, $\mathrm{mg}$ & $C_{o}$ & $C_{f}$ & $E, \%$ \\
\hline 100 & 2.55 & 2.43 & 5 \\
\hline 200 & 2.55 & 2.32 & 9 \\
\hline 500 & 2.55 & 2.08 & 18 \\
\hline 800 & 2.55 & 1.90 & 25 \\
\hline 1000 & 2.55 & 0.54 & 79 \\
\hline
\end{tabular}

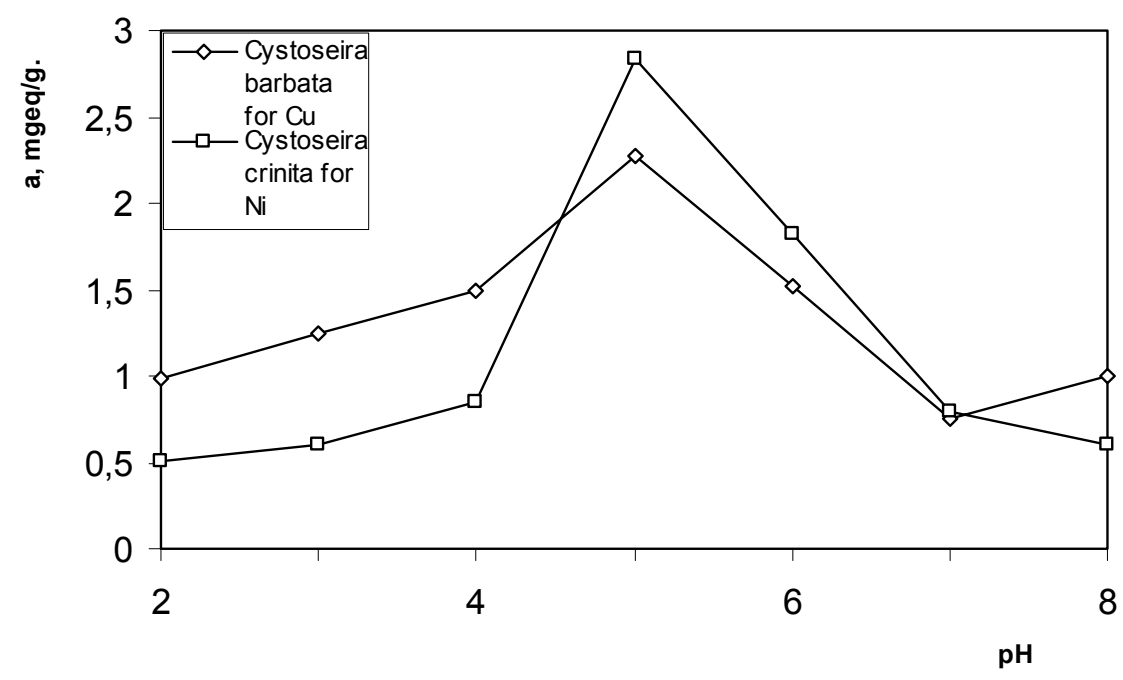

Fig. 7. Effect of initial $p H$ on heavy metal sorption

Вісник Дніпропетровського університету. Біологія, екологія.

Vìsnik Dnìpropetrovs'kogo unìversitetu. Serìa Bìologiâ, ekologîâ Visnyk of Dnipropetrovsk University. Biology, ecology. Vìsn. Dnìpropetr. Unìv. Ser. Bìol. Ekol. 2007. 15(1).

ISSN 2310-0842 print ISSN 2312-301X online www.ecology.dp.ua 
The uptake for both sorbents showed a sharp increase with an increase in $p H$ from 2.0 to 5.0. This could be explained with the extend of protonation which is determined by the $p H$. The amino and carboxyl groups, and nitrogen and oxygen of the peptide bonds are available for coordination bonding with metal ions. Such bond formation could be accompanied by displacement of protons [11]. At lower $p H$ values $(p H=2,3)$ the concentration of protons $\left(\mathrm{H}^{+}\right)$was increased and showed preponderance over that of heavy metal ions which could explain the lower sorption uptake of the algae in this $p H$ range. Both sorbents reached highest uptake at $\mathrm{pH} 5$ (C. crinita $-2.84 \mathrm{mgeq} \mathrm{Ni}^{2+} / \mathrm{g}, \mathrm{C}$. barbata $\left.-2.28 \mathrm{mgeq} \mathrm{Cu}^{2+} / \mathrm{g}\right)$.

\section{Conclusion}

The results obtained showed that Cystoseira crinita, C. barbata and Ulva rigida could be used as efficient biosorbent material for treatment of heavy metal ions. Highest uptake was reached by Cystoseira crinita for $\mathrm{Ni}$ (II) and $\mathrm{C}$. barbata for $\mathrm{Cu}$ (II). The desorption experiments suggested that the regeneration of the biosorbents was possible for repeated use especially with regard to $C d$ (II). The good sorption characteristics with respect to heavy metals and the availability of the algae in great quantities in nature, makes these biosorbents very perspective for successful purification of industrial waters.

\section{References}

1. A review of potentially low-cost sorbents for heavy metals / S. Bailey, T. Olio, R. Bricka, D. Adrian // Water Res. - 1999. - Vol. 33. - P. 2469-2479.

2. Biosorption of copper (II) and lead (II) from aqueous solutions by nonliving green algae Cladophora fascicularis: equilibrium, kinetics and environmental effects / L. Dend, Y. Su, H. Su et al. // Chemistry and Materials Sci. - 2006. - Vol. 12, N 4. - P. 267-277.

3. Copper removal from aqueous solution bu marine green algae Ulva reticulate / K. Vijauaraghavan, J. Jegan, K. Planivetu, M. Velan // Electronic Journal of Biotechnology. - 2004.

4. Davis T. Sargassum seaweed as biosorbent for heavy metals / T. Davis, B. Volesky, R. Vieira // Wat. Res. -2000 . - Vol. 34. - P. 4270-4278.

5. Davis T. A review of the biochemistry of heavy metal biosorption of brown algae / T. Davis, B. Volesky, A. Macei // Water Research. - 2003. - Vol. 37, N 18. - P. 4311-4330.

6. Fourest E. Alginate properties and heavy metal biosorption by marine algae / E. Fourest, B. Volesky // Appl. Biochem. Biotechnol. - 1997. - Vol. 67. - P. 44-44.

7. Handy A. Removal of $P b^{2+}$ by biomass of marine algae // Current Microbiology. - 2000.Vol. 41, N 4. - P. 232-243.

8. Karthikeyan S. Evaluation of the marine algae Ulva fasciata and Sargassum spp. for the biosorption of $\mathrm{Cu}$ (II) from aqueous solutions / S. Karthikeyan, R. Baluslabramiun, C. S. P. Lyer // Bioresource Technology - 2007. - Vol. 98. - P. 452-453.

9. Kinetic and equilibrium studies of lead and cadmium biosorption from aqueous solution by Sargassum spp. biomass / R. Nabizadeh, K. Naddafi, R. Saeedu et al. / Iran J. Health Sct. Eng. 2005. - Vol. 2, N 3. - P. 159-168.

10. Matheickal J. Biosorption of lead (II) and copper (II) by pretreated biomass of Australian marine algae / J. Matheickal, O. Yu // Bioresource Tech. - 1999. -Vol. 69. - P. 223-229.

11. Microbial biosorbents: meeting challenges of heavy metal pollution in aqueous solutions / R. Gupta, P. Ahuja, S. Khan et al. // Current Sci. - 2000. - Vol. 78, N 8. - P. 967-973.

12. Ofer R. Marine macroalgae as biosorbents for Cadmium and Nickel in water / R. Ofer, A. Yerachmiel, J. Shumel // Water Environment Research. - 2003. - Vol. 75, N 3. - P. 246-253.

13. Schiewer S. Ionic strength effects in biosorption of metals by marine algae / S. Schiewer, M. H. Wong // Chemosphere. - 2000. - Vol. 41, N 1-2. - P. 271-282.

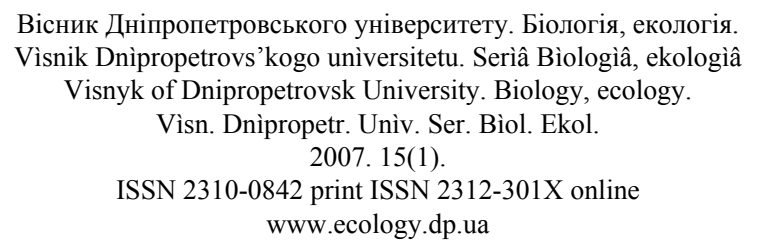


14. Screening of hexavalent chromium biosorbent from marine algae / D. Lee, C. Park, J. Yang et al. // Appl. Microbiology and Biotechnol. - 2000. - Vol. 54, N 3. - P. 445-448.

15. Vieira R. Biosorption: a solution to pollution / R. Vieira, B. Volesky // Internat. Microbiol. 2000. - Vol. 3. - P. 17-24.

16. Volesky B. Advances in biosorption of metals: selection of biomass types // FEMS Microbiol. Rev. - 1994. - N 14. - P. 291-302.

17. Volesky B. Biosorption of heavy metals / B. Volesky, Z. Holan // Biotechnol. Prog. - 1995. N 11. - P. 235-250.

18. Volesky B. Development of heavy metal biosorption process / B. Volesky, J. Weber, M. Park // Water Res. - 2001. - Vol. 37, N 2. - P. 297-306.

Надійшла до редколегії 11.06.2007

Вісник Дніпропетровського університету. Біологія, екологія.

Vìsnik Dnìpropetrovs'kogo unìversitetu. Serîa Bìologiâ, ekologìâ Visnyk of Dnipropetrovsk University. Biology, ecology. Vìsn. Dnìpropetr. Unìv. Ser. Bìol. Ekol. 2007. 15(1).

ISSN 2310-0842 print ISSN 2312-301X online www.ecology.dp.ua 